\title{
Skills for sustainable development: Transforming vocational education and training beyond 2015
}

\author{
Simon McGrath ${ }^{\mathrm{a}, \mathrm{b}, *}$, Lesley Powell ${ }^{\mathrm{a}, \mathrm{c}}$ \\ a University of Nottingham, United Kingdom \\ ${ }^{\mathrm{b}}$ University of the Western Cape, South Africa \\ ${ }^{\mathrm{c}}$ Nelson Mandela Metropolitan University, South Africa
}

\section{A R T I C L E I N F O}

\section{Article history:}

Received 25 January 2016

Received in revised form 13 May 2016

Accepted 23 May 2016

Available online 6 June 2016

\section{Keywords:}

VET

Human development

Sustainable development

\begin{abstract}
A B S T R A C T
There have been recent calls to transform VET and to transform development. This double call leads us to ask how can skills development best support development that is sustainable for individuals, communities and the planet, and which promotes social justice and poverty reduction. In considering this question, we critique the idea of green skills for the green economy as being inadequate for achieving a transformed and transformative VET that shifts the target from economic growth to the wellbeing of individuals and that enables vocational education to play a role in challenging and transforming society and work. Rather, we argue that we must see human development and sustainable development as inseparable, and plan and evaluate VET for its contribution to these. Such an approach must be grounded in a view of work, and hence skills for work, that is decent, life-enhancing, solidaristic, environmentallysensitive and intergenerationally-aware. It must confront the reality that much current VET is complicit in preparing people for work that lacks some or all of these characteristics. It must be concerned with poverty, inequality and injustice and contribute to their eradication. It must be supportive of individuals' agency, whilst also reflecting a careful reading of the structures that too often constrain them. In doing all this it must minimise the costs and risks of any transformation for the poor and seek to lock them into better individual and communal lives, not out of them. Finally, it must transform skills, work and the world in ways that are truly sustainable of the people of today but also of those who are to inhabit the earth tomorrow.
\end{abstract}

(c) 2016 Elsevier Ltd. All rights reserved.

\section{Introduction}

The Sustainable Development Goals (SDGs), launched in 2015 in the United Nation's publication Transforming our World (UN, 2015), are intended to provide an "ambitious and transformational vision" (UN, 2015: 3) designed to free "the human race from the tyranny of poverty and to heal and secure our planet" (UN, 2015: 1). In contrast to the Millennium Development Goals (MDGs), which did not have a goal targeted specifically towards vocational education and training (VET), VET is a central aspect of Goal 4 of the SDGs which seeks to "ensure inclusive and equitable quality education and promote lifelong learning opportunities for all" (UN, 2015: 17). This is the second important international call in recent years for the transformation of VET so as to better support

\footnotetext{
* Corresponding author at: School of Education, University of Nottingham, Nottingham NG8 1BB, England.

E-mail address: simon.mcgrath@nottingham.ac.uk (S. McGrath).
}

development. In 2012, the Third International Congress on Technical and Vocational Education and Training offered a vision of "transformative VET" that meant both that "the target of VET [changes] from economics to individuals", and that VET "does not adapt to current work and societal change, but aims to challenge and transform those" (UNESCO, 2012). This included an emphasis on human development and the need to think more seriously about skills for life as well as for work.

In response to the 2012 call for a "transformative VET", one of us posed the question of "what is skills development for?" (McGrath, 2012). That article explored the challenge of updating debates about VET to address recent thinking about human development. In response to the SDGs' call for transformation, we revisit that earlier question about VET's purpose by seeking to revitalise the debate about vocational education and sustainable development. We do this by exploring further the intrinsic links between human development and sustainable development, which were only touched lightly upon in the earlier article. The key question we want to pose here is: 
- how can skills development best support development that is sustainable for individuals, communities and the planet, whilst promoting social justice and poverty reduction?

Skills development can only play a small role within the wider systemic and cultural transformations that are necessary for sustainable development to be achieved, yet that role is not insignificant given the crucial place that skills are allocated both in articulating between education and active citizenship, and between schooling and work. VET has made a rapid return as an international policy priority since 2010 but much of the approach remains locked into old ways of thinking about skills, work and development that are still narrowly focused on economic rationales, formal wage employment and industrial modernisation that are little changed from the 1960s. For VET to contribute to addressing sustainable development we need nothing less than a "reimagining [of] the role of vocational education and training" (Powell, 2014).

In development terms, transformation is urgently required as we face a triple crisis that combines environmental degradation that pushes beyond the limits of what the Earth and its environmental systems can sustain (Rockström et al., 2009); continued and increasing chronic levels of poverty and inequality in poorer countries; and a new emergency caused by the effects of austerity in richer countries that sees the poor becoming poorer in absolute as well as relative terms, whilst the rich continue to revel in unsustainable consumption.

However, the "reimagining" required for a transformation of VET has not yet been well developed and the green skills approach, discussed below, does not go far enough to support an agenda of "transforming our world". Therefore, this article offers a new way of thinking how the transformative agendas for VET and sustainable development might be advanced together. Our intention is to be provocative and to open up a new debate, rather than provide an authoritative account. Fundamentally, we take an epistemological and ethical stance that the questions we raise can only be answered in specific contexts and through participatory processes.

Before proceeding, we need to be clear as to what we are talking about in terms of skills development for sustainable development. We are focused here on what might be broadly considered as vocational skills: to be learned in vocationally-oriented provider institutions (public and private) and enterprises (formal and informal). That is not to argue that life skills for sustainable development, taught within the school system, are not important (cf. Fien et al., 2009b); but to clarify that they are not our focus.

We will begin to identify and examine some elements of an approach to answering the question of how VET can best support development that is sustainable for individuals, communities and the planet, and which promotes social justice and poverty reduction. In doing so, we will build on our previous arguments about skills development for human development to stress the crucial link between human and sustainable development through emphasising the sustainable development aspect more (cf. McGrath, 2012; Powell, 2012, 2014; Powell and McGrath, 2014; McGrath and Powell, 2015).

We do this by exploring in the next section the ambiguity and tension that exists in the term "sustainable development". This is followed by a discussion of the dominance in initial responses to VET for sustainable development of the idea of "green skills for the green economy". Thereafter we critique the notions of "green skills" and the "green economy" by arguing that it is unlikely that the approach that is being taken will achieve either the environmental sustainability that it has targeted or the social justice goals which have been set. In this section we also critique the notion of green skills as being inadequate for achieving a transformed and transformative VET that shifts the target from economic growth to the wellbeing of individuals and that enables vocational education to play a role in challenging and transforming society and work, and hence "our world". In our penultimate section we begin the discussion of a more radical account of skills for sustainability, before concluding with a summary of our argument and its significance.

\section{What is sustainable development?}

We need to unpack what is meant by the term "sustainable development" for, as Rist (2008) notes, “'sustainable development' has become part of the language of every 'developer' . . . [with] no project taken seriously ... unless it has an 'environmental aspect' (Rist (2008): 192). A growing awareness of environmental issues became visible in the 1960s and early 1970s (e.g., Carson, 1962; Boulding, 1966; Meadows et al., 1972) but the term 'sustainable development' was popularised in 1987 by the Brundtland Commission report, Our Common Future. The Brundtland Report defined sustainable development as "meet[ing] the needs of the present without compromising the ability of future generations to meet their own needs" (World Commission on Environment and Development, 1988: 8).

Rist (2008) usefully explains that the term is used in a manner that binds together two ambiguous and potentially contradictory terms: environmental sustainability and economic development. For Brundtland, it was possible to find a happy medium that generated enough economic growth and enough environmental protection:

Humanity has the ability to make development sustainable-to ensure that it meets the needs of the present without compromising the ability of future generations to meet their own needs. The concept of sustainable development does imply limits-not absolute limits but limitations imposed by the present state of technology and social organization on environmental resources and by the ability of the biosphere to absorb the effects of human activities. But technology and social organization can be both managed and improved to make way for a new era of economic growth. ... Poverty is not only an evil in itself, but sustainable development requires meeting the basic needs of all ... A world in which poverty is endemic will always be prone to ecological and other catastrophes (World Commission on Environment and Development, 1988: 8).

However, Rist argues that the power of sustainable development as a concept is that it allows for a masking of the tensions between growth and environment. He suggests that it permits environmental activists and ecologists to be supportive of the ecological maintenance aspect implied by the term, whilst also enabling governments and NGOs that are committed to economic growth as the developmental solution to poverty and unemployment to describe this as sustainable. Simultaneously, it facilitates corporations driving towards accelerated profit to commit to increased awareness of the impact of production on the environment, despite making very few changes to production processes and being under no legislative requirement to do so. The result is that the term sustainable development allows for many different and contradictory images to be held by those who support and participate in advancing the endeavour and for the notion, thereby, "to play on different registers" (Rist, 2008: 212).

A number of authors reject the elision of growth and environment and question whether sustainable development can be constructed out of a greening of capitalism (sometimes described as weak sustainability-cf. Pelenc et al., 2013). They instead point to a fundamental conflict as environmental 
sustainability requires a contraction in humanity's production and consumption; whilst economic growth requires an expansion in both production and consumption (e.g., Jackson, 2009; D'Alisa et al., 2014a). As Klein (2014: 21) graphically puts it: "our economic system and our planetary system are now at war".

For Klein, it is clear that neoliberalism is a core contributor to unsustainable development, as witnessed in environmental degradation, rising poverty and the persistence of indecent jobs. Moreover, she sees neoliberalism as one period in a longer history of extractivism, an approach since the "discovery of the new World" to fuelling the industrial growth of the North through the extraction of Southern natural and human resources (Acosta, 2013). It is argued that this constant theme of the global political economy of the last 500 years, cannot simply be "greenwashed" away.

\section{Green skills for a green economy}

What is promoted as the dominant definition of sustainability is essential for understanding the likely role for skills development in sustainable development. In the economic growth perspective, a core aspect is the contention that growth can and must continue. In this view, sustainable development will come from market-based solutions and through voluntary agreements. Economic growth remains of greater importance than the environment with the underlying belief being that a trade-off between them can be avoided through new technologies. These new technologies, it is hoped, will not only reduce environmental degradation but will generate new products, services and industries, thus ensuring that the market dynamic is a sustainable engine of future sustainable development. The argument is that "it is not only possible to have prosperity, jobs and inclusive growth in a low-carbon economy but also that a low-carbon economy is the only way that we will have prosperity, jobs and inclusive growth in the future" (MartinezFernandez and Hinojosa, 2010: 255).

In the VET arena policy work on this issue has been far more prominent than academic work. UNESCO-UNEVOC, in particular, has been an important voice for greening skills (UNESCO-UNEVOC, 2005; Fien et al., 2009b; UNESCO-UNEVOC, 2015). UNESCO has also been working with other agencies, most notably Cedefop, ILO and OECD, to develop a concerted approach to green skills, as reflected most clearly in the Inter-Agency Working Group's policy recommendations on "meeting skill needs for green jobs" (IAWG, 2013) and Cedefop and OECD's two recent Green Skills Fora (Martinez-Fernandez et al., 2013; Cedefop and OECD, 2015).

From this perspective, skills for sustainable development is about developing the skills to support the growth of the green economy, or "green skills for green jobs". The International Labour Organisation, for example, argues in its report Skills for Green Jobs that skills development is critical to "unlocking the employment potential of green growth" and, indeed, that the creation of green skills is a necessary condition for the successful transition to a greener economy (Strietska-Ilina et al., 2011: v). The CedefopOECD Green Skills Fora emphasised the link between skills and knowledge needs and inclusive green growth (Martinez-Fernandez et al., 2013; Cedefop and OECD, 2015). This is further supported and reinforced by the policy trajectory committed to by individual nations. The United Kingdom, for example, has developed its policy on Skills for a Green Economy, which begins with a discussion of the "opportunity" and "huge, long term potential" that the green economy provides for "both environmental stability and financial growth" (HM Government, 2011: 6).

Green jobs are defined by Strietska-Ilina et al. (2011: 4) as “jobs that reduce the environmental impact of enterprises and economic sectors, ultimately to levels that are sustainable". These will be focused on new green manufacturing and service jobs such as solar panel installation or ecotourism. At its most developed, this approach is linked to attempts to build new green sectors which, it is hoped, will achieve the twin goals of financial growth, by enabling new industries and markets, and environmental stability, by enabling the move towards a lower emissions trajectory.

The approach is rooted in a human capital reading of VET. It is focused on both identifying the specific training needs of current or potential green sectors and the wider skills needs associated with making other industries greener. In recognition of the latter challenge, the UK Skills for a Green Economy report argues:

All workers will need the abilities and knowledge to respond effectively to the shift to greener business practices. FE and HE both have a role in embedding skills for a green economy in their courses and ensuring teachers, trainers, lecturers and assessors have the necessary capabilities to undertake this widening role (HM Government, 2011: 7).

There is a growing concern that market failures mean that "skill shortages already constrain the transition to a greener economy" (Strietska-Ilina et al., 2011: v). This is seen as justifying new incentives to employers and further interventions on the supplyside to improve public skills development, as implied in the above quotation.

\section{Green skills as a hollow promise}

However, the policy trajectory which sees the green economy as achieving both a reduction in environmental risk and ecological scarcities and an improvement in human wellbeing is hardly likely to be achieved. There are a number of strong reasons for scepticism.

A first concern lies with the assumption that green skills will kick-start the green economy. The assumption that education and training leads to economic growth and therefore that green skills will lead to growth in the green economy is in danger of recycling simplistic notions of a linear relationship of cause and effect between education and economic growth. Such notions have already been widely challenged in the literature on skills (e.g., Keep and Mayhew, 1999; Wolf, 2002). One major problem of simple forms of human capital assumptions is that they are blind to the way that political economy affects the education-skills-workdevelopment complex. A large literature exists that insists on the complex ways in which institutional arrangements develop over time to produce national skills regimes (e.g., Crouch et al., 1999; Brown et al., 2001; McGrath et al., 2004; Thelen, 2004; Busemeyer and Trampusch, 2011). This perspective suggests that "transition to a green economy" will only occur as the result of an evolutionary process within a specific regime.

The second concern is that there is uncertainty as to whether the green economy will impact in any meaningful way on poverty alleviation. The notion that increased growth will lead to poverty alleviation is challenged by the human development approach that argues that economic growth does not necessarily reduce poverty as the economic benefits are not evenly distributed across the society (Sen, 1999). As a result, many countries that have high growth rates have not achieved a commensurate growth in quality of life, whilst there are countries with relatively moderate growth that have achieved a high quality of life (Anand and Sen, 2000). Furthermore, the idea that green skills will open opportunities in the labour market for the poor is questionable. Rather than reap expected benefits, women and men living in poverty may face rising energy prices, restricted access to forest resources and the collapse of the "dirty" (or "brown") sectors in which they were employed. At the same time, anticipated job opportunities and national investments in green infrastructure are unlikely to reach the poorest at any meaningful scale (Raworth et al., 2014). There is 
also some indication in initial studies that the jobs created in the green economy tend towards higher skill levels and are, for the most part, located in cities rather than in rural areas where the biggest poverty crisis resides (Fien and Guevara 2013). Indeed, as Cedefop and OECD researchers admit: “workers losing 'brown' jobs are not always able to walk into green alternatives, especially lowskilled and medium-skilled workers" (Ranieri and MartinezFernandez 2015: 15).

The third concern relates to the question of whether green jobs will be the decent jobs that are predicted. Despite wish lists included in almost every policy document about "improved human well-being and social equity" and "decent work", the push towards creating enabling environments for the growth of green economies has resulted in the deregulation of labour markets, which does not bode well for the development of decent work (MartinezFernandez and Hinojosa, 2010). Other than rhetoric about maximising the "creation of decent work" (Strietska-Ilina et al., 2011), there is very little, if any, attention or legal protection provided to ensure the quality of this work.

This links to a fourth concern, which is about the problematic account of work that underpins the notion of green jobs. It is implicitly grounded in a neoclassical view of work, which has been subjected to long-standing critiques from a variety of positions (cf. Marx, 2007; Leo XIII, 1891; Sen, 1975; Power, 2004; UNDP, 2015) that argue that work should be seen as an integral part of selfactualisation and human wellbeing. The notion of work that underpins the understandings of green jobs presupposes that economic growth and work (as paid employment) are permanent and necessary features of human existence, regardless of their adverse impact and consequences on human beings and the environment. In opposition to this, Motala (2015: 26) promotes the notion of "socially useful work" to describe "the idea of work that is not confined in the grip of wage-labour" but instead focuses on the "creative uses of its abilities for the production and distribution of socially useful goods and services untainted by the power of profitfor-some and its pernicious social consequences". An explicitly environmental dimension of this argument is provided by Jackson (2009), D'Alisa et al. (2014b) and Klein (2014: 82), the latter describing the necessary approach as "growing the caring economy, shrinking the careless one".

Moving more specifically to the skills domain, it is apparent that the green skills agenda is far less radical than UNESCO's vision of a transformed VET, which aims to shift the purpose of VET away from economic growth to the wellbeing of individuals. The green skills account is negligent of the role that VET is to play in challenging and transforming society and work. We have already developed a critique of the VET orthodoxy in earlier papers (especially McGrath, 2012; Powell, 2014; McGrath and Powell, 2015) but we will briefly return to this as it impinges upon the green skills approach. There are three main elements to this argument.

First, VET has been characterised as being locked "into a blinkered race for 'global economic competitiveness' which ignores the ecological costs of training for a growth-oriented industrial system and the increasing irrelevance of skills-forwork ..." (Anderson, 2009: 44). Anderson argued that orthodox VET was grounded in two key assumptions: (i) that training leads to productivity, leads to economic growth (training for growth) and (ii) that skills lead to employability, lead to jobs (skills for work). "Green skills" does not seriously address Anderson's critique. Rather, it is located within broader neoliberal policies of economic growth which include a human capital perspective as an integral element. There seems to be no questioning of an old faith in "a virtuous circle between skill formation, industrial productivity and economic growth, leading to increased employment opportunities and individual earnings" (Anderson, 2008: 115).
Second, as such, green skills offer nothing to a wider critique of VET as being anti-humanist in its attitude to individuals and communities. Nor does it do anything to move us away from the orthodox Anglophone notion of employability that focuses on the skills, knowledge and attitudinal deficits of young people rather than the failings of firms, governments or the global capitalist system.

Third, the human capital underpinning of green skills has opened green skills to all the weaknesses of human capital approaches (cf. Ashton and Green, 1996; Lauder, 2015). At the level of supply and demand, and notwithstanding the flood of reports on green skills that attempt to identify the potential areas of priority and scarce skills within the green economy, very little is known about the implications of the green economy for labour markets or for what the future skill requirements of the green economy would be. Specifically, we know very little about which jobs the green economy might create (Martinez-Fernandez and Hinojosa, 2010). Despite pronouncements of the possibilities that green skills have for job creation, there is little evidence and little information as to how jobs created within the green economy will weigh off against the joblessness that occurs in brown industries.

All of this means that the green skills agenda is not part of a meaningful approach to transformative VET. There is nothing in it that meaningfully addresses the humanistic potential and imperative of VET (cf. McGrath 2012; McGrath and Powell, 2015). Moreover, there is a real danger that a narrow focus on the supply of green skills serves to deflect and distract from deeper structural inequalities that are the fundamental causes of unemployment and poverty (Vally and Motala, 2014). As such, this agenda appears to have little to offer to any meaningful notion of sustainable development.

\section{Skills for sustainability: towards a more radical approach}

Notwithstanding our critique, there are some signs of a more radical agenda within certain UN documents. Whilst underdeveloped, the UNESCO “transformative VET" notion clearly can point to a more radical view of sustainability and should be understood within UNESCO's wider humanist perspective (UNESCO 2015). UNEP's 2011 Green Economy Pathways to Sustainable Development and Poverty Eradication also points to a more radical position. It defines the green economy as,

One that results in improved human well-being and social equity, while significantly reducing environmental risks and ecological scarcities. In its simplest expression, a green economy can be thought of as one which is low carbon, resource efficient and socially inclusive. ... one in which material wealth is not delivered perforce at the expense of growing environmental risks, ecological scarcities and social disparities (UNEP, 2011: 1 and 14).

We began this article with a statement about the importance of "reimagining the purpose of VET" in the light of the launch of the Sustainable Development Goals in September 2015. What then do the SDGs have to say? There is not space here for a full analysis but, at least on one level, the SDGs can be read as a strong statement of the importance of moving away from productivism, extractivism and neoliberalism. The main slogans (UN, 2015: 2) include an emphasis on people, prosperity (which includes living fulfilling lives) and the planet, all of which are to be welcomed. However, the real test of the SDGs does not lie in the text but in the implementation. Of course, at this moment it is far too early to judge that implementation, and it would be fallacious to simply read off a global account of inevitable failure or likely significant progress. Rather, the SDG's fruit will be ripened in myriad local, national and global struggles to capture their "true" meaning. 
At this point then, what can we tell from reading the SDGs? What notion of sustainable development is actually contained within them, and what implications does this have for skills development?

As is the case with such documents, there is some stirring rhetoric about "people-centred development":

27. We will seek to build strong economic foundations for all our countries. Sustained and inclusive economic growth is essential for prosperity. We will work to build dynamic, sustainable and people-centred economies, promoting youth employment in particular and decent work for all. ...

28. We commit to making fundamental changes in the way that our societies produce and consume goods and services. Governments, international organisations, the business sector and other non-state actors and individuals must contribute to changing unsustainable consumption and production patterns ... (UN, 2015: 8).

There are some powerful pointers to a more radical sustainable development approach in this text. However, there is also much that hints at the inevitable compromises that have been struck. Clearly, there is much here that is about continuing with productivity and growth, whilst hoping to make this greener, in ways that are not always hugely apparent.

In some ways the SDGs' vision for transformation does chime with an older tradition of an integrated sustainable development approach (Fien et al., 2009a), which focuses on human, community and intergenerational development; that keeps us within/moves us back towards planetary boundaries (Holland 2008; Rockström et al., 2009); that reduces poverty and inequality; that promotes individual and community wellbeing; and builds agency, solidarity and subsidiarity. In the words of Raworth, Wykes and Bass, such development is "green and just", built on four principles:

- reduction of poverty and/or deprivation

- equality of opportunities or capabilities

- fairness of process

- limited disparity of outcomes (Raworth et al., 2014: 8).

How can skills development engage with such a vision? Here we can only set out some core principles for a skills development for integrated sustainable development approach. We introduce four of these:

- a strong focus on human development

- a theory of sustainable work

- a political economy of skills account

- a theory and practice of change that minimise the costs and risks, and maximises the likely benefits, of any transformation for the poor

\subsection{A strong focus on human development}

Our existing work on skills development for human development (cited above, and see also Wheelahan and Moodie, 2011; DifPradalier et al., 2012; López-Fogués 2012; Tikly, 2013) is consistent with a sustainable development agenda. Indeed, it is most pertinent in that it talks to a purpose for vocational education that is focused on human development, rather than on human resource development through employability. In this perspective, the processes of learning to become a fuller person are core to the purpose of vocational education (Nussbaum, 2000). This is to do with the development of learners' agential capabilities to engage in and transform their worlds and the expansion of their "capability to aspire" (Powell, 2012).
In this agentic focus it shows continuity with the Deweyian liberal tradition (Leßmann, 2009) of VET philosophy as well as UNESCO's broader approach to education as represented in the Faure and Delors Reports. Like those reports, it sees this process of learning as inherently lifelong and lifewide.

\subsection{A theory of sustainable work}

The 2015 Human Development Report (HDR), entitled "work for human development", makes a powerful statement regarding the way that work can both thwart and enable human potential. On the enabling side, it argues that

The link between work and human development is synergistic. Work enhances human development by providing incomes and livelihoods, by reducing poverty and by ensuring equitable growth. Human development - by enhancing health, knowledge, skills and awareness - increases human capital and broadens opportunities and choices (UNDP, 2015: 3).

However, this is contrasted with the experience of millions of "corrosive and exploitative activities [that] shatter human development ... eroding their well-being" (UNDP, 2015: 40). As Sayer (2012) argues, whether work facilitates or blocks the achievement of capabilities is partly a function of the quantity of work available. Being unable to work enough to earn a decent income undermines many other capabilities and functionings, as does being forced to devote too much time to work. His argument is deepened by Sehnbruch (2008) who notes that the contribution of work to human development also depends on its quality. Even much work that is not particularly dirty, dangerous or exploitative may be simply tedious and injurious to self-esteem.

Sayer also stresses that a human development account of work needs to pay clear attention to work in households. Overwhelmingly, such labour is unevenly distributed between the genders in both quantity and quality terms. This has profound effects on women's human development:

in effect they allow men to enlarge some of their capabilities at the expense of women's. It also handicaps women's participation in public life in general and the labour market in particular. (Sayer, 2012: 586)

Waring et al. (2011) describe how this can place women carers in "capability servitude".

HDR 2015 also addresses the notion of sustainable work. It argues that "sustainable work is critical not only for sustaining the planet but also for ensuring work that continues to advance human development for future generations." (UNDP, 2015: 148). This concept is indeed critical.

In building our own account of sustainable work, we draw crucially on Bonvin and Farvaque's concept of the capability for work. They argue that employability and waged labour do not provide for a capability to voice, or a genuine concern with agency or, for that matter, any concern with the decency of work opportunities available. In contrast, their notion of a capability for work is "not identified as the mere possibility to get an adequate wage, it focuses on the agency dimension, that is the capability to participate in society" (Bonvin and Farvaque, 2006: 128 ) and the ability to choose. Indeed, that choice may include the right not to work, with its echoes of Lefargue's "right to be lazy" (Lefargue, 1883), a notion taken up again in recent years by the degrowth movement (D'Alisa et al., 2014a).

In a more recent account, Bonvin returns to the importance of an approach that provides people with the ability to choose the work that they do and the contribution that they would like to make in society (Bonvin and Galster 2010). As Gorz has argued, 
to change society, we need to change 'work'-and vice versa. To change it by divesting it of all its reifying constraints (hours, hierarchy, productivity), which reflect its subordination to capital and which, so far, have determined the essence of what is currently known as 'work'. . . . to live it as an activity merged in the flow of life, a path to the full development of the senses, towards power over oneself and the external world, and as a bond with others (Gorz, 1999: 98-99).

This seems central to any notion of sustainable and human work but is profoundly challenging to the conventional orthodoxies and critiques of VET, both of which are still focused on the primacy of the economy and of formal work.

Indeed, we need to ask how sustainable it is for skills development to still be about jobs and growth. This would lead on to a discussion of how far can skills development be about greener, more local, pro-resilient work. Equally, drawing on Catholic, feminist economics and community development traditions, we need to open up difficult debates about VET and voluntary work and caring. We would want to draw positively on important intellectual resources that talk about caring work that is reproductive of humanity, society and the Earth (e.g., Cahn, 2000; Pontifical Council for Justice and Peace, 2004; Power, 2004). However, we must also acknowledge that there is also a more pernicious neoliberal drive towards volunteering as an attempted way out of dealing with some of the consequences of neoliberalism. In Britain, for instance, the attack on the state in the name of austerity has not only reduced many direct services but has also drastically reduced local government grants to third sector organisations. This forces such organisations to survive through volunteers taking over work that was once paid. As feminist scholars have always stressed, decisions over what counts as paid or unpaid work, and who loses out through this, are never neutral. How VET supports socially just practices in this arena is in urgent need of much more thought.

\subsection{A political economy of skills account}

All of this must be backed by a political economy reading that robustly engages with why the world is in the state it is in, and with the obstacles to genuinely sustainable development; whilst maintaining the courage to hope for a better future. There is a strong political economy of skills tradition (noted above), which emphasises the need to see skills development as a complex process that has local, national and international dimensions and which is profoundly influenced by cultural, economic, political, social and technological factors.

However, there remains a challenge of linking such strongly structural accounts with the more micro and agential focus of the human development tradition (cf. Sayer, 2012). Here Gough's (2004) approach to wellbeing may be valuable in the way that he combines the agentic focus of authors such as Sen and Nussbaum with structural theories such as that of Esping-Andersen (1990).

\subsection{A pro-poor theory and practice of transformation}

As Raworth et al. (2014) argue, it is essential that any approaches to skills for sustainability minimise the costs and risks of any transformation for the poor and make them secure in enjoying the positive aspects of sustainable development. As noted above, the poor and marginalised are most likely to find themselves doing the dirtiest, most precarious, indecent work. Yet, this is often better than no work at all, and badly designed greening initiatives are likely to do away with significant amounts of the work that the poorest do and the incomes and livelihoods thus generated. Moreover, at the same time, such policies will often reduce their access to cheap (though unsustainable) fuels and other resources, thus pushing them further into poverty. Furthermore, as conventional green jobs are typically higher skilled and higher status, those lacking human and other capitals are unlikely to be able to access them.

It is vital, therefore, that new green policies are based in rigorous analyses of how they are likely to affect the most precarious, and include specifically pro-poor dimensions. Safeguarding and compensation may be important, but the greatest sustainability will come where policies and practices work with what the poorest know and can do in order to be simultaneously green and just.

What is the skills dimension of this? In particular, how does VET, so often the route to further learning of the poor and educationally disadvantaged, equip participants to be more skilful and powerful actors in working for sustainability and human flourishing?

\section{Conclusion}

In line with Anderson (2008), we argue that

a post-productivist vision of [vocational education] is required; one in which productivism is superseded by a new ethos that rejects the untenable myth of perpetual economic growth and accepts ecologically sustainable development as the bedrock of [vocational education] (2008: 107).

This post-productivist vision of skills development and the role that it is to play in sustainable development is yet to be developed. We argue that it is vital to revisit Anderson's call after both UNESCO's commitment to "transformative" VET and the branding of the SDGs as an agenda for "transforming our world" in order to assess whether we are indeed moving towards a new approach to skills development for sustainable development.

We caution against the rush of policymakers and international aid agencies to plan for green skills, green jobs and green economies. These are ultimately not transformative as they neither accord sufficient agency to individuals nor confront the fundamental tensions that lie at the heart of sustainable development. Nor is the vision of skills development contained within them genuinely transformative. Rather, the dominant approach to green skills sits comfortably alongside narrow notions of employability; deficit accounts of learners' failings to develop the skills necessary to be good consumer-citizens; a human capital set of assumptions that are blind to the role of institutions and political economy; and an account of work that is still fundamentally productivist. Moreover, though the SDGs and important UN reports such as the 2015 Human Development Report talk about decent work, they say almost nothing about skills development as a contributor to this. In part, the blame lies with the skills development community, which is failing to say enough that resonates with emerging global agendas.

In mounting this critique, we are painfully conscious that we are talking against the vast majority of research and policy thinking in the VET field. However, we are strongly convinced that this position needs writing. Such writing is difficult, not least because it is so untypical of a field that tends to be characterised by work that sits squarely in one disciplinary tradition, most typically economics or sociology. However, the important questions here require a consideration of a wide range of literatures. Thus this paper draws from a range of fields to point towards a new way of doing VET research that genuinely engages with questions about its purpose in the face of both the triple crisis that we identified earlier and, more positively, in response to new practical initiatives to build sustainable communities. 
We argue that the reimagined purpose of VET should be grounded in a view of work, and hence skills for work, that is decent, life-enhancing, solidaristic, gender-aware, environmentally-sensitive and intergenerationally-minded. Such a view must confront the reality that much current VET is complicit in preparing people for work that lacks some or all of these characteristics, something of which some of our own writings have also been guilty. A genuine approach to skills for sustainability must be concerned with poverty, inequality and injustice and contribute to their eradication. It must be supportive of individuals' agency, whilst also reflecting a careful reading of the structures that too often constrain them. In doing all this it must minimise the costs and risks of any transformation for the poor and seek to facilitate them into better individual and communal lives, not limit their opportunities for these. Finally, it must transform skills, work and the world in ways that are truly sustainable of the people of today, but also of those who are to inhabit the earth tomorrow.

\section{References}

Acosta, A., 2013. Extractivism and neoextractivism: two sides of the same curse. In: Lang, M., Mokrani, D. (Eds.), Beyond Development: Alternative Visions from Latin America. Rosa Luxemburg Foundation and Transnational Institute, Quito and Amsterdam.

Anand, S., Sen, A., 2000. Human development and economic sustainability. World Dev. 28 (12), 2029-2049.

Anderson, D., 2008. Productivism, vocational and professional education, and the ecological question. Vocations Learn. 1 (1), 105-129.

Anderson, D., 2009. Productivism and ecologism: changing dis/courses in TVET. In: Fien, J., Maclean, R., Park, M.-G. (Eds.), Work, Learning and Sustainable Development. Springer, Dordrecht.

Ashton, D., Green, F., 1996. Education, Training and the Global Economy. Edward Elgar, Cheltenham.

Bonvin, J.-M., Farvaque, N., 2006. Promoting capability for work: the role of local actors. In: Deneulin, S., Nebel, M., Sagovsky, N. (Eds.), Transforming Unjust Structures: The Capability Approach. Springer, Dordrecht.

Bonvin, J.-M., Galster, D., 2010. Making them employable or capable? Social integration policies at a crossroads. In: Otto, H.-U., Ziegler, H. (Eds.), Education, Welfare and the Capabilities Approach. Barbara Burdich, Opladen.

Boulding, K., 1966. The Economics of the Coming Spaceship Earth. . (accessed 27.11.15.) http://dieoff.org/page160.htm.

Brown, P., Green, A., Lauder, H., 2001. High Skills: Globalization, Competitiveness, and Skill Formation. Oxford University Press, Oxford.

Busemeyer, M., Trampusch, C. (Eds.), 2011. The Political Economy of Collective Skill Formation. Oxford University Press, Oxford.

Cahn, E., 2000. No More Throw-Away People. Essential, Washington.

Carson, R., 1962. Silent Spring. Houghton Mifflin, Boston.

Cedefop, OECD (Eds.), 2015. Green Skills and Innovation for Inclusive Growth. Publications Office of the European Union, Luxembourg.

Crouch, C., Finegold, D., Sako, M., 1999. Are Skills the Answer? Oxford. University Press, Oxford.

D’Alisa, G., Demaria, F., Kallis, G. (Eds.), 2014. Degrowth: A Vocabulary for a New Era. Routledge, Abingdon.

D’Alisa, G., Deriu, M., Demaria, F., 2014b. Care. In: D’Alisa, G., Demaria, F., Kallis, G. (Eds.), Degrowth: A Vocabulary for a New Era. Routledge, Abingdon.

Dif-Pradalier, M., Rosenstein, E., Bonvin, J.-M., 2012. Vocational training as an integration opportunity for struggling young adults? A Swiss case study. Social Work Soc. 10, 1 (online journal).

Esping-Andersen, G., 1990. The Three Worlds of Welfare Capitalism. Polity, Cambridge.

Fien, J., Guevara, J., 2013. Skills for a green economy: practice, possibilities, and prospects. In: Maclean, R., Jagannathan, S., Sarvi, J. (Eds.), Skills Development for Inclusive and Sustainable Growth in Developing Asia-Pacific. Springer, Dordrecht.

Fien, J., Goldney, D., Murphy, T., 2009a. Rethinking development: as if the planet and its people really mattered. In: Fien, J., Maclean, R., Park, M.-G. (Eds.), Work, Learning and Sustainable Development. Springer, Dordrecht.

Fien, J., Maclean, R., Park, M.-G. (Eds.), 2009. Work, Learning and Sustainable Development. Springer, Dordrecht.

Gorz, A., 1999. Reclaiming Work. Polity, Cambridge.

Gough, I., 2004. Human well-being and social structures. Global Social Policy 4 (3), 289-311.

HM Government, 2011. Skills for a Green Economy: A Report on the Evidence. HMSO, London.

Holland, B., 2008. Ecology and the limits of justice. J. Hum. Dev. 9 (3), 401-425.

Inter-Agency Working Group on Greening Technical and Vocational Education and Training and Skills Development, 2013. Meeting skill needs for green jobs: policy recommendations. ILO, Geneva.

Jackson, T., 2009. Prosperity Without Growth: Economics for a Finite Planet. Earthscan, London.
Keep, E., Mayhew, K., 1999. Evaluating the assumptions that underlie training policy In: Ahier, J., Esland, G. (Eds.), Education, Training and the Future of Work I. Routledge, London.

Klein, N., 2014. This Changes Everything: Capitalism vs. the Climate. Simon and Schuster, London.

López-Fogués, A., 2012. Theorising further education through a capability lens: vulnerability and freedoms. Jubilee Working Papers. School of Education, University of Nottingham.

Lauder, H., 2015. Human capital theory, the power of transnational companies and a political response in relation to education and economic development. Compare 45 (3), 490-493.

Leßmann, O., 2009. Capability and learning to choose. Stud. Educ. Philo. 28, 449460.

Lefargue, P., 1883. The Right to Be Lazy. Charles Kerr, Chicago.

Leo, 1891. Rerum Novarum. . (accessed 27.11.15.) http://w2. vatican.va/content/leoxiii/en/encyclicals/documents/hf_l-xiii_enc_15051891_rerum-novarum.html.

Martinez-Fernandez, C., Hinojosa, C., 2010. Green Jobs and Skills: The Local Labour Market Implications of Addressing Climate Change. . (accessed: 27.11.15.) http:// www.oecd.org/cfe/leed/44683169.pdf.

Martinez-Fernandez, C., Ranieri, A., Sharpe, S., 2013. Greener skills and jobs for a low-carbon future. OECD Green Growth Papers 2013-10. OECD Publishing, Paris.

Marx, K., 2007. Economic and Philosophic Manuscripts of 1844. Dover, Mineola (1844).

McGrath, S., Powell, L., 2015. Vocational education and training for human development. In: McGrath, S., Gu, Q. (Eds.), Routledge Handbook on International Education and Development. Routledge, Abingdon.

McGrath, S., Badroodien, A., Kraak, A., Unwin, L. (Eds.), 2004. Shifting Understandings of Skills in South Africa: Overcoming the Historical Imprint of a Low Skills Regime. HSRC Press, Cape Town.

McGrath, S., 2012. Vocational education and training for development. Int. J. Educ. Dev. 32 (5), 623-631.

Meadows, D.H., Meadows, D.L., Randers, J., Behrens, W., 1972. The Limits to Growth. Universe Books, New York.

Motala, E., 2015. Unemployment, Work and Learning: Is Work Synonymous with Paid-labour or Jobs? A Brief Historical Examination. Nelson Mandela Institute, University of Fort Hare and the Education Policy Consortium, Johannesburg (work in progress).

Nussbaum, M., 2000. Women and Human Development: The Capabilities Approach. Cambridge University Press, Cambridge.

Pelenc, J., Lompo, M., Ballet, J., Dubois, J.-L., 2013. Sustainable human development and the capability approach. J. Hum. Dev. Capabilities 14 (1), 77-94.

Pontifical Council for Justice, Peace, 2004. Compendium of the Social Doctrine of the Church. Libreria Editrice Vaticana, Vatican City.

Powell, L., McGrath, S., 2014. Exploring the value of the capability approach for vocational education and training evaluation: reflections from South Africa. Int. Dev. Policy 5, 126-148.

Powell, L., 2012. Reimagining the purpose of VET: expanding the capability to aspire in South African further education and training students. Int. J. Educ. Dev. 32 (5), 643-653.

Powell, L., 2014. Reimagining the purpose of vocational education and training: the perspectives of further education and training college students in South Africa. Unpublished PhD Thesis. University of Nottingham.

Power, M., 2004. Social provisioning as a starting point for feminist economics. Feminist Econ. 10 (3), 3-19.

Ranieri, A., Martinez-Fernandez, C., 2015. The social and employment dimensions of a greener economy. In: Cedefop, OECD (Eds.), Green Skills and Innovation for Inclusive Growth. Publications Office of the European Union, Luxembourg.

Raworth, K., Wykes, S., Bass, S., 2014. Securing Social Justice in Green Economies: A Review and Ten Considerations for Policymakers. IIED, London.

Rist, G., 2008. The History of Development. Zed, London.

Rockström, J., Steffen, W., Noone, K., Persson Å, Chapin III, F., Lambin, E., Lenton, T., Scheffer, M., Folke, C., Schellnhuber, H., Nykvist, B., DeWit, C., Hughes, T., vanderLeeuw, S., Rodhe, H., Sörlin, S., Snyder, P., Costanza, R., Svedin, U., Falkenmark, M., Karlberg, L., Corell, R., Fabry, V., Hansen, J., Walker, B., Liverman, D., Richardson, K., Crutzen, P., Foley, J., 2009. Planetary boundaries: exploring the safe operating space for humanity. Ecol. Soc. 14 (2), 32.

Sayer, A., 2012. Capabilities, contributive injustice and unequal divisions of labour. J. Hum. Dev. Capabilities 13 (4), 580-596.

Sehnbruch, K., 2008. From the quantity to the quality of employment: an application of the capability approach to the Chilean labour market. In: Comim, F., Qizilbash, M., Alkire, S. (Eds.), The Capability Approach Concepts, Measures and Applications. Cambridge University Press, Cambridge.

Sen, A., 1975. Employment, Technology, and Development. Clarendon Press, Oxford.

Sen, A., 1999. Development as Freedom. Oxford University Press, Oxford.

Strietska-Ilina, O., Hofmann, C., DuranHaro, M., Jeon, S., 2011. Skills for Green Jobs: A Global View. International Labour Organisation, Geneva.

Thelen, K., 2004. How Institutions Evolve: The Political Economy of Skills in Germany, Britain, the United States and Japan. Cambridge University Press, Cambridge.

Tikly, L., 2013. Reconceptualising TVET and development: a human capability and social justice approach. Revisiting Global Trends in TVET. UNESCO-UNEVOC, Bonn.

UN, 2015. Transforming Our World: the Agenda for Sustainable Development. (accessed 27.11.15.) https://sustainabledevelopment.un.org/post2015/ transformingourworld. 
UNDP,, 2015. Human Development Report 2015: Work for Human Development. Oxford University Press, New York.

UNEP,, 2011. Towards a Green Economy: Pathways to Sustainable Development and Poverty Eradication. UNEP, Nairobi.

UNESCO, 2012. Background report for the UNESCO World Congress on TVET, Shanghai, May.

UNESCO, 2015. Rethinking Education. UNESCO Paris.

UNESCO-UNEVOC, 2005. Learning for Work, Citizenship and Sustainability: Final Report. UNESCO-UNEVOC, Bonn.

UNESCO-UNEVOC, 2015. Global Forum Report: Global Forum on Skills for work and life: post 2015, 14-16 October 2014, Bonn, Germany. UNESCO-UNEVOC, Bonn.
Vally, S., Motala, E. (Eds.), 2014. Education, Economy and Society. UNISA Press, Pretoria.

Waring, M., Carr, R., Mukherjee, A., Shivdas, M., 2011. Who Cares? Economics of Dignity. Commonwealth Secretariat, London.

Wheelahan, L., Moodie, G., 2011. Rethinking Skills in Vocational Education and Training: From Competencies to Capabilities. New South Wales Board of Vocational Education and Training, Darlinghurst.

Wolf, A., 2002. Does Education Matter? Myths About Education and Economic Growth. Penguin, Harmondsworth.

World Commission on Environment and Development, 1988. Our Common Future. Oxford University Press, Fontana, London. 